\title{
Comparison of growth and psychomotor development in daycare centers attended by professionals
}

\author{
Enrique Villarreal-Ríos ${ }^{1 *}$, Cynthia Cruz-Hernández², Karina Morales-Morales ${ }^{3}$, Emma R. Vargas-Daza ${ }^{1}$, \\ Liliana Galicia-Rodríguez ${ }^{1}$, Dulce M. Isassi-González ${ }^{4}$, and Eduardo Guzmán-Padilla ${ }^{5}$ \\ ${ }^{1}$ Unidad de Investigación Epidemiológica y en Servicios de Salud Querétaro, Instituto Mexicano del Seguro Social (IMSS); ${ }^{2}$ Medicina Familiar, \\ Unidad de Medicina Familiar No 16 Querétaro, IMSS; ${ }^{3}$ Departamento de Guarderías Querétaro, IMSS; ${ }^{4}$ Guardería Carrillo Puerto, IMSS; ${ }^{5}$ Consultor \\ Independiente en Seguridad Social. Querétaro, Querétaro, Mexico
}

\begin{abstract}
Background: Growth and development reflect the child's health condition. Currently, child care is supported in daycare centers. In this context, this article aimed to identify the differences in growth and psychomotor development in children according to their attendance at daycare centers. Methods: We conducted an analytical cross-sectional study in children aged 25 to 48 months. Two groups were identified: 68 children attended daycare, and 68 children did not attend daycare. Growth was assessed with weight-for-height curves, and psychomotor development was evaluated with the child developmental assessment instrument (psychosocial, language, psychomotor, and cognitive area). The $\mathrm{X}^{2}$ test was used for statistical analysis. Results: The percentage of daycare children with ideal weight was higher than those not attending in daycare $(p=0.035)$. Psychomotor development was significantly higher in daycare children: in the psychosocial $(p=0.000)$, language $(p=0.000)$, motor $(p=0.000)$, and cognitive development $(p=0.000)$ areas. Conclusions: The psychomotor development of children attending daycare centers is superior to that of children not in daycare centers.
\end{abstract}

Keywords: Growth. Psychomotor development. Preschool child. Child care. Daycare center.

\section{Comparación del crecimiento y desarrollo psicomotor en guarderías atendidas por profesionales}

\section{Resumen}

Introducción: La salud del niño se puede evaluar a partir de su crecimiento y desarrollo. En la sociedad actual, el cuidado de los hijos se comparte con las guarderías infantiles. En este contexto, el objetivo del artículo fue identificar las diferencias de crecimiento y desarrollo psicomotor en niños de acuerdo con su asistencia a las guarderías. Métodos: Se llevó a cabo un estudio transversal analítico en niños de 25 a 48 meses de edad. Se identificaron dos grupos: 68 niños atendidos en guarderías y 68 niños no atendidos en guarderías. El crecimiento se evaluó con las curvas de peso para la talla y el desarrollo psicomotor, con el instrumento de evaluación del desarrollo del niño (área psicosocial, lenguaje, psicomotriz, y cognitiva). Se utilizó la prueba de $\mathrm{X}^{2}$ para el análisis estadístico. Resultados: El porcentaje de niños de guardería con peso ideal es superior al de los no atendidos en guardería $(p=0.035)$. El desarrollo psicomotor es significativamente mayor en los

Correspondence:

*Enrique Villarreal-Ríos

E-mail: enriquevillarrealrios@gmail.com

Available online: $16-12-2021$

Date of reception: 08-04-2021 Date of acceptance: 29-07-2021 DOI: 10.24875/BMHIM.21000068
Bol Med Hosp Infant Mex. 2021;78(6):565-570

www.bmhim.com 1665-1146/@ 2021 Hospital Infantil de México Federico Gómez. Published by Permanyer. This is an open access article under the CC BY-NC-ND license (http://creativecommons.org/licenses/by-nc-nd/4.0/). 
niños de guardería: en el área psicosocial $(p=0.000)$, en lenguaje $(p=0.000)$, en el área motriz $(p=0.000)$ y en desarrollo cognitivo $(p=0.000)$. Conclusiones: El desarrollo psicomotor de los niños atendidos en guardería es superior al de los niños no atendidos en guardería.

Palabras clave: Crecimiento. Desarrollo psicomotor. Preescolar. Cuidado del niño. Centros de día.

\section{Introduction}

In traditional families, the mother and father are responsible for the care of the children. However, in practice, specific roles have been assigned: the father is identified with the role of provider, and the mother is responsible for the daily care of children. In today's society, these roles have been reassigned. As women have been incorporated into the workforce, the initial role of caregiver has lost its validity. However, it does not mean that the child's need for care has disappeared. Therefore, the social response resulted in the creation of centers responsible for the care and attention of the children of working mothers. Subsequently, this condition was modified by law to include any children, regardless of the mother's occupation, and recently was extended to include the children of working fathers ${ }^{1-4}$. In addition to being a physical place, this initiative aims to represent a space that fosters psychomotor development and growth of the child ${ }^{5-8}$.

Today, depending on the institution to which they belong, these centers are identified as childcare, child development assistance, or daycare centers staffed by health and education professionals. The child stays in these centers 8-10 hours a day ${ }^{9}$.

As a program derived from a health policy, daycare centers require periodic evaluation to generate feedback to determine the program's validity and propose supportive or corrective measures. Within daycare centers, health professionals have designed and coordinated activities oriented to the growth and psychomotor development of the child without becoming an early stimulation program.

Psychomotor development is understood as the acquisition or improvement of biological, psychological, or social functions that reflect cognitive, behavioral, or socialization processes and determine the degree of development as a reflection of the child's health status ${ }^{10-13}$.

Several instruments are used to assess the psychomotor development of the child. Some institutions have constructed instruments taking others as a reference and respecting the psychomotor development evaluation expected for the age. These instruments are applied at the national level in all daycare centers belonging to the same system ${ }^{2,14-17}$.
In addition to psychomotor development, growth is another indicator of a child's health conditions. Child growth is a biological process that corresponds to the increase in body weight or volume ${ }^{18}$. The instruments for assessing growth are diverse, including height-forage, weight-for-age, and weight-for-height. In this regard, the World Health Organization has proposed weight-for-height curves, a method institutionally adopted as a standard for assessing the nutritional status of children ${ }^{19}$.

In this context, daycare centers follow a specific program implemented by professionals in education, nutrition, and child health derived from a health policy that can be evaluated. The literature is abundant regarding the effectiveness of these programs on children's growth and development. However, ongoing evaluation of public policies is mandatory. In addition, these publications reinforce the proposal to extend the daycare program in specific centers to all infants ${ }^{20,21}$. Therefore, the study aimed to identify differences in growth and psychomotor development between children attending daycare centers and those receiving home care.

\section{Methods}

From September to October 2019, we conducted a cross-sectional analytical study with children aged 25 to 48 months belonging to families of factory workers, merchants, and office workers affiliated ${ }^{22}$ to a Social Security Institution in the City of Querétaro, Mexico.

According to daycare attendance, two groups of children were identified:

- The daycare group included children who received care in centers designed to promote adequate growth and psychomotor development of the child and attended by professional staff with specific training (educators, nurses, and nutritionists). The evaluation of psychomotor development and growth upon leaving the daycare center (mean age 38.29 months) was carried out in children who remained in the center for 32.11 months.

- The non-daycare group included children who did not attend daycare and were cared for at home by their 
parents or relatives. This group was evaluated at 39.16 months of age.

Both groups were located in the same geographical area and belonged to the same socioeconomic level.

The professionals responsible for the care of children in the group of daycare centers included those with training oriented to education (educators), health (nurses), and nutrition (nutritionists). The program applied in daycare centers included pedagogy (developmental stimulation for habit formation, integration, and community life), health promotion (medical evaluation, early detection of pathologies, vaccination, and growth monitoring), and nutrition (healthy, varied, and sufficient diet administered at defined times) ${ }^{15,16}$.

The daycare group included children attending a center for at least one year, and information on their growth and psychomotor development was available. For the non-daycare group, we considered children identified in the waiting room of the medical unit who attended as companions, whose mothers were willing to provide information and allow the evaluation of the child. For both groups, children whose medical history indicated any congenital pathology, food allergy, or underlying pathology that could interfere with growth and psychomotor development were excluded.

The sample size (68 per group) was calculated using the mean formula for two populations, with a confidence level of $95 \%(Z \alpha=1.64)$ and a test power of $80 \%$ ( $Z \beta=$ $0.84)$, assuming that adequate or normal cognitive development in the daycare group was $62.7 \%\left(p_{1}=0.627\right)$ and adequate or normal cognitive development in the non-daycare group was $41.8 \%\left(p_{2}=0.418\right)$. To estimate the percentages, we used as a reference what has been published in the literature ${ }^{23}$. This value was modified based on empirical evidence from daycare center personnel and researchers. The sample size was calculated for the four areas (psychosocial, language, cognitive, and motor), and we adopted the largest size resulting from the estimation of cognitive development.

The sampling technique was performed non-randomly by consecutive cases. In the daycare group, the sampling frame used was the list of children registered in the daycare information and administration system. In the non-care group, sampling was performed on children accompanying their parents who came to request a health service at the medical unit.

Data on the age and sex of the children were included. Regarding nutritional status, we used the World Health Organization charts for girls and boys, which include weigh-for-length in children $<2$ years of age and weightfor-height from 2 to 5 years of age (severe wasting, $<3$ standard deviations (SD); wasting, < 2 SD; normal, < 1 SD; ideal, mean value; normal with a possible risk of overweight, > 1 SD; overweight, > 2 SD; obesity, > 3 SD) $)^{24}$.

Psychomotor development was measured with the Child Development Evaluation instrument proposed and validated by the Head of Daycare Centers of the Institution. For the evaluation, the children were divided into four age groups: 25 to 30 months, 31 to 36 months, 37 to 42 months, and 43 to 48 months. Psychosocial, language, psychomotor, and cognitive development were evaluated in each group. The expected development for each age group was used as a reference, and it was verified whether they complied with it. The instrument had three possible responses: yes (with a score of 1), sometimes (with a score of 0.5 ), and no (with a score of 0 ). For each area and age group, the number of items evaluated ranged from 4 to 11. According to each one of the age groups, the number of items was as follows: psychosocial area, 6, 8, 8, and 8 items, respectively; language area, 8, 8, 8, and 6 items, respectively; motor area, $8,11,8$, and 8 items, respectively; and cognitive area, 4, 4, 10, and 11 items, respectively. The score obtained in each area was added up and multiplied by 100 and then divided by the number of items in the respective area. The result obtained on a scale from 0 to 100 was considered normal when the score was $\geq$ $75^{15}$. In this regard, the results of children in non-daycare centers were similar to those reported in the literature.

The fieldwork was carried out by a third-year physician of the Family Medicine Specialty. Before data acquisition, the nursery staff (nurses and educators) trained the researcher to collect the information and standardize the procedures ${ }^{16}$.

To collect the information on the daycare children, the responsible researcher went to the daycare center, accessed the Daycare Information and Administration System, identified and reviewed the file of each of the children. From this, children were individually evaluated, and the database was constructed. To collect information on non-daycare center children, the researcher went to the medical unit located in the same geographic area as the daycare center. Once in the waiting room, children who attended as companions of the parents were identified, and the parents' authorization was requested to carry out the evaluation and answer the questionnaire. Parents who agreed to participate were invited to come to the office designated for the research, where the researcher applied the Child Development Evaluation instrument. In addition, the weight and measurements of each child were recorded using the same scale (Royal) and the same stadiometer (BAME). 
Statistical analysis included means, standard deviation, percentages, t-test for two independent populations, z-test for two independent populations, and $\mathrm{X}^{2}$ test.

The protocol was registered with the Institution's Research Committee and Bioethics Committee, and informed consent was obtained from the mother or father of the children. When alterations in growth and development were identified, children were referred to the Institution's Family Physician to initiate the study and treatment protocol.

\section{Results}

The study included 68 children in the daycare group and 68 children in the non-daycare group. The mean age of the daycare children was $38.29 \pm 4.93$ months, and that of the non-daycare children, $39.16 \pm$ 5.73 months $(t=0.94, p=0.34)$. In the daycare group 50\% were female, and in the non-daycare group, $51.1 \%(z=0.02, p=0.86)$.

All children who attended the daycare center presented normal development in the psychosocial area. In contrast, $77.9 \%$ of the children who did not attend a center presented adequate or normal development in the same area $(p=0.000)$ (Table 1).

Of the children who did not attend a daycare center, $79.4 \%$ showed normal language development, while this area was shown in $100 \%$ of children who attended daycare centers $(p=0.000)$ (Table 1). Concerning motor development, $100 \%$ of the children who attended daycare presented adequate or normal motor development, but only $75.0 \%$ in children who did not attend daycare $(p=0.000)$ (Table 1). All children who attended daycare centers presented adequate or normal cognitive development, and in the group that did not attend daycare centers, the percentage was $69.1 \%(p=0.000)$ (Table 1).

Differences between groups were observed in all four areas when the developmental assessment was performed on a discrete scale. For example, on the cognitive development scale, daycare children scored $95.25 \pm 5.37$, and children who did not attend daycare scored $78.95 \pm 22.52$ (difference of 16.30 points, $t=5.80, p=0.00$ ). The information for the other areas is shown in Table 2.

According to the weight-for-length and weight-forheight anthropometric indexes proposed by the World Health Organization, we identified that $89.7 \%$ of the children in the daycare group presented ideal growth, while the percentage was $69.1 \%$ in the non-daycare group $\left(X^{2}=10.34, p=0.035\right.$ ) (Table 3 ).
Table 1. Comparison of psychosocial, language, motor, and cognitive development of children according to daycare attendance

\begin{tabular}{|c|c|c|c|c|}
\hline \multirow[t]{2}{*}{ Development } & \multicolumn{2}{|c|}{ Percentage } & \multirow[t]{2}{*}{$x^{2}$} & \multirow[t]{2}{*}{$p$-values } \\
\hline & $\begin{array}{l}\text { Daycare } \\
(n=68)\end{array}$ & $\begin{array}{c}\text { Non-daycare } \\
(n=68)\end{array}$ & & \\
\hline $\begin{array}{l}\text { Psychosocial } \\
\text { development } \\
\text { Adequate or } \\
\text { normal } \\
\text { Abnormal }\end{array}$ & $\begin{array}{c}100.0 \\
0.0\end{array}$ & $\begin{array}{l}77.9 \\
21.1\end{array}$ & 16.86 & 0.000 \\
\hline $\begin{array}{l}\text { Language } \\
\text { development } \\
\text { Adequate or } \\
\text { normal } \\
\text { Abnormal }\end{array}$ & $\begin{array}{c}100.0 \\
0.0\end{array}$ & $\begin{array}{l}79.4 \\
20.6\end{array}$ & 15.60 & 0.000 \\
\hline $\begin{array}{l}\text { Motor } \\
\text { development } \\
\text { Adequate or } \\
\text { normal } \\
\text { Abnormal }\end{array}$ & $\begin{array}{c}100.0 \\
0.0\end{array}$ & $\begin{array}{l}75.0 \\
25.0\end{array}$ & 19.42 & 0.000 \\
\hline $\begin{array}{l}\text { Cognitive } \\
\text { development } \\
\text { Adequate or } \\
\text { normal } \\
\text { Abnormal }\end{array}$ & $\begin{array}{c}100.0 \\
0.0\end{array}$ & $\begin{array}{l}69.1 \\
30.9\end{array}$ & 24.83 & 0.000 \\
\hline
\end{tabular}

\section{Discussion}

As an organized group, society responds to the population's needs by implementing effective public policies or policies that require adjustments for their proper functioning. One of these is the response to children's care and development needs when parents join the workforce. In this case, daycare centers or kindergartens can be evaluated as health services. In this context, the present study evaluated the growth and development of children attending these centers.

There are reports in the literature related to the psychomotor development of children attending daycare centers. However, when the effectiveness of public policies is questioned, science has the academic obligation to issue positions from an objective point of view, based on a rigorous analysis using the scientific method. Childcare centers have incorrectly adopted the term daycare centers. Therefore, it must be recognized that continuing to use this term stigmatizes the activity performed in these places and the health care workers, the children, and society itself. The concept of daycare has been surpassed in practice. Consequently, institutions must understand the notion to be named according to their functions and the great responsibility they bear. 
Table 2. Comparison of psychomotor development scores of children according to daycare attendance

\begin{tabular}{|c|c|c|c|c|c|}
\hline \multirow[t]{2}{*}{ Group } & \multicolumn{3}{|c|}{ Score } & \multirow[t]{2}{*}{$t$} & \multirow{2}{*}{$\begin{array}{c}p \text { - } \\
\text { values }\end{array}$} \\
\hline & Mean & SD & Difference & & \\
\hline $\begin{array}{l}\text { Psychosocial } \\
\text { development } \\
\text { Non-daycare } \\
\text { (n=68) } \\
\text { Daycare } \\
\text { (n=68) }\end{array}$ & $\begin{array}{l}84.28 \\
97.48\end{array}$ & $\begin{array}{r}16.37 \\
4.87\end{array}$ & 13.20 & 6.37 & 0.00 \\
\hline $\begin{array}{l}\text { Language } \\
\text { development } \\
\text { Non-daycare } \\
\text { (n=68) } \\
\text { Daycare } \\
\text { (n=68) }\end{array}$ & $\begin{array}{l}80.60 \\
91.60\end{array}$ & $\begin{array}{c}20.24 \\
6.25\end{array}$ & 10.99 & 4.28 & 0.00 \\
\hline $\begin{array}{l}\text { Motor } \\
\text { development } \\
\text { Non-daycare } \\
\text { ( } n=68 \text { ) } \\
\text { Daycare } \\
\text { (n=68) }\end{array}$ & $\begin{array}{l}81.19 \\
96.05\end{array}$ & $\begin{array}{r}17.56 \\
4.54\end{array}$ & 14.85 & 6.79 & 0.00 \\
\hline $\begin{array}{l}\text { Cognitive } \\
\text { development } \\
\text { Non-daycare } \\
\text { (n=68) } \\
\text { Daycare } \\
(n=68)\end{array}$ & $\begin{array}{l}78.95 \\
95.25\end{array}$ & $\begin{array}{c}22.52 \\
5.37\end{array}$ & 16.30 & 5.80 & 0.00 \\
\hline
\end{tabular}

$\mathrm{SD}$, standard deviation.

Table 3. Comparison of children's growth (weight for height) according to daycare attendance

\begin{tabular}{|l|c|c|c|c|}
\multirow{2}{*}{$\begin{array}{l}\text { Nutritional } \\
\text { status }\end{array}$} & \multicolumn{2}{|c|}{$\mathbf{n}(\%)$} & \multirow{2}{*}{$X^{2}$} & p-values \\
\cline { 2 - 3 } & $\begin{array}{c}\text { Daycare } \\
(\mathbf{n = 6 8 )}\end{array}$ & $\begin{array}{c}\text { Non-daycare } \\
(\mathbf{n}=68)\end{array}$ & & \\
\hline Normal & $2(2.9)$ & $2(2.9)$ & 10.34 & 0.035 \\
\hline Ideal & $61(89.7)$ & $47(69.1)$ & & \\
\hline $\begin{array}{l}\text { Normal with } \\
\text { risk of } \\
\text { overweight }\end{array}$ & $4(5.9)$ & $16(23.5)$ & \\
\hline Overweight & $1(1.5)$ & $2(2.9)$ & \\
\hline Obese & $0(0.0)$ & $1(1.5)$ & \\
\hline
\end{tabular}

World Health Organization charts for boys and girls include weigh-for-length in children under two years of age and weight-for-height from 2 to 5 years of age. Normal $(<1$ standard deviation), ideal (mean), normal with the possible risk of overweight ( $>1$ standard deviation), overweight ( $>2$ standard deviations), obese (>3 standard deviations).

To guarantee an objective evaluation and use the same criteria for comparison between groups (daycare and non-daycare), health personnel who assessed the daycare group trained the person responsible for assessing the non-daycare group. This scenario can be considered a strength of the study. The Child Development Evaluation instrument was created when the daycare system was implemented in the institution and is still valid for the entire system at the national level; however, it should be recognized as a limitation of the study. When comparing the results presented in the non-daycare group with those reported in the literature, the values are very similar: in the non-daycare group, the prevalence of inadequate development fluctuates between $25 \%$ and $30 \%$. In this regard, the clinical practice guideline on specific psychomotor development disorders identifies a prevalence of $11 \%$ and $16 \%$ and suggests that the prevalence in Mexico is unknown. However, other reports identify a prevalence between $11 \%$ and $35 \%$, depending on the area evaluated ${ }^{25-27}$.

Admittedly, the research was conducted in two groups with a specific socioeconomic stratum, limiting the results' generalizability; in this case, extrapolation of the results can be made to the socioeconomic stratum analyzed. This scenario, which initially could be considered a limitation, allows us to measure the impact of the actions generated by the daycare center since it controls for factors that can be indirectly confounding when comparing members of different socioeconomic strata, including the difference in feeding patterns at home. It could be assumed that growth and development will behave differently in other socioeconomic strata, mainly due to the characteristics of the risk factors inherent in the environment. It is likely that the difference between daycare and non-daycare children is more pronounced in the low socioeconomic status and is more similar in the high socioeconomic status, but this is only a hypothesis that corresponds to another research project.

Our findings identified differences in psychomotor development in the four areas studied between the daycare and non-daycare groups. The most significant difference was observed in cognitive development and the least significant difference in language development. Claiming that children's development is better when they attend daycare centers has implications. Therefore, there must be a logical argument to support this claim. This observation can be possible because the programs implemented in the daycare centers, without being an early stimulation program, include continuous and systematized actions that favor the child's development, a scenario described in the literature consistent with our findings ${ }^{6,28}$. To sustain this statement would mean that the child who does not attend daycare is at a disadvantage, and consequently, there should be a public policy to address this problem. However, this is only a 
hypothesis since the research design does not allow us to be conclusive. Therefore, a causality study is necessary to be able to conclude on this issue.

Despite finding a statistically significant difference in growth between the groups, it was not the same magnitude as that identified in psychomotor development. A possible explanation would be to consider susceptibility and constancy of stimulation for nutrient intake. When addressing the nutritional aspect, greater vulnerability is identified; in this aspect, the periodicity of adequate nutrient intake and overstimulation by unnecessary nutrients play a determining role. It is a reality that children who attend daycare centers, upon returning home, are exposed to the family's eating habits, so the control of the diet implemented in the daycare center fails. However, differences in the growth of children between groups were present and statistically significant.

In conclusion, growth and psychomotor development in psychosocial, language, motor, and cognitive areas in children enrolled in a daycare program and cared for by healthcare, nutrition, and education professionals are different from the growth and psychomotor development of children not enrolled in these programs.

\section{Ethical disclosures}

Protection of human and animal subjects. The authors declare that no experiments were performed on humans or animals for this study.

Confidentiality of data. The authors declare that they have followed the protocols of their work center on the publication of patient data.

Right to privacy and informed consent. The authors have obtained the written informed consent of the patients or subjects mentioned in the article. The corresponding author has this document.

\section{Conflicts of interest}

The authors declare no conflict of interest.

\section{Funding}

None.

\section{References}

1. Páez Patrón JV. Programa de guarderías y estancias infantiles para apoyar a madres trabajadoras. Rev Latinoam Derecho Soc. 2007;5:247-50.

2. Cámara de Diputados LXIII Legislatura. Centro de Estudios Sociales y de Opinión Pública. Información estadística. Mexico City: Guarderías y Estancias Infantiles en México; 2016. Available from: http://www.CESOP-IL-14-CI53GuarderiasEstanciasInfantiles-160608\%20(2).pdf
3. Guarderías privadas. La elección de cuidar lo más preciado. Mexico: Procuraduría Federal del Consumidor; 2017. Available from: www.gob. $\mathrm{mx} /$ profeco

4. Diario Oficial de la Federación. Decreto por el que se reforman los artículos 201, primer párrafo, y 205, primer párrafo de la Ley del Seguro Social. Mexico: Secretaría de Gobernación; 2020.

5. Arce M. Crecimiento y desarrollo infantil temprano. Rev Peru Med Exp Salud Publica. 2015;32:574-8.

6. Medina Salas A. La estimulación temprana. Rev Mex Med Fis Rehab. 2002;14:63-4.

7. Núñez-Rocha GM, Meléndez-Buitrón MA Salinas-Martínez AM, Elva-dela-Garza-Casas Y, Garza-Elizondo ME, Villarreal-Ríos E. Guarderías infantiles, un espacio para la vigilancia alimentaria y nutricional. Rev Invest Clin. 2010;62:54-62.

8. Romero Fuentes A, Rivera Landero E. Análisis tipos de aplicaciones para guarderías, identificando ventajas y desventajas de su uso. Ingenio Concienc Bol Cient Esc Super Ciudad Sahagún. 2021;8:35-9.

9. Norma para la operación del servicio de guardería. Dirección de Prestaciones Económicas y Sociales. Mexico City: Instituto Mexicano del Seguro Social; 2018. Available from: http://siag.imss.gob.mx/instalacionsiag/Guarderias/Normas/Archivos/2018/Normas/3000 -001-018-Norma-Operacion-Guarderias.pdf.

10. Martínez y Martínez R. Salud y enfermedad del niño y adolescente. Mexico City: Manual Moderno; 2017.

11. Coutiño León B. Desarrollo psicomotor. Rev Mex Med Fis Rehab. 2002;14:58-60.

12. Schonhaut BL, Álvarez LJ, Salinas AP. El pediatra y la evaluación del desarrollo psicomotor. Rev Chil Pediatr. 2008;79:26-31.

13. Cabezuelo G, Frontera P. El desarrollo psicomotor: desde la infancia hasta la adolescencia. Madrid: Narcea Ediciones; 2016.

14. Orcajo-Castelán R, Sidonio-Aguayo B, Alcacio-Mendoza JA, López-Díaz GL. Análisis comparativo de pruebas de tamiz para la detección de problemas en el desarrollo diseñadas y validadas en México. Bol Med Hosp Infant Mex. 2015;72:364-75.

15. Procedimiento de pedagogía del servicio de guardería de prestación indirecta. Dirección de Prestaciones Económicas. Mexico City: Instituto Mexicano del Seguro Social; 2018. Available from: http://siag.imss.gob.mx/instalacionsiag/Guarderias/Normas/Archivos/2018/Indirecta/Pedagogia/PedagogiaPI.pdf

16. Procedimiento del fomento de la salud del servicio de guardería de prestación indirecta. Dirección de Prestaciones Económicas y Sociales. Mexico City: Instituto Mexicano del Seguro Social; 2018. Available from: http://siag.imss.gob.mx/instalacionsiag/Guarderias/Normas/Archivos/2018/Indirecta/Fomento/FomentoSaludPI.pdf

17. Aprendizajes clave para la educación integral. Un buen comienzo. Programa para la educación de las niñas y los niños de 0 a 3 años. Mexico City: Secretaría de Educación Pública; 2017. Available from: https://www. planyprogramasdestudio.sep.gob.mx/descargables/biblioteca/inicial/1Educacion-Inicial_Digital.pdf

18. Donzeau A, Bouhours-Nouet N, Coutant R. Crecimiento pondoestatural normal. EMC Pediatría. 2016;51:1-11.

19. Patrones de crecimiento infantil de la OMS. Longitud/estatura para la edad, peso para la edad, peso para la longitud, peso para la estatura e índice de masa corporal para la edad. Métodos y desarrollo. Departamento de Nutrición para la Salud y el Desarrollo. Geneva: World Health Organization; 2020. Available from: https://www.who.int/childgrowth/standards/tr_summary_spanish_rev.pdf?ua $=1$

20. Ángeles G, Gadsden P, Galiani S, Gertler P, Herrera A, Kariger P, et al. Evaluación de impacto del Programa Estancias Infantiles para Apoyar a Madres Trabajadoras. Informe final de la evaluación de impacto. Cuernavaca: Centro de Investigación en Evaluación de Encuestas; 2011.

21. Urzúa S, Veramendi G. The impact of out-of-home childcare centers on early childhood development. Washington D.C.: Inter-American Development Bank; 2010.

22. Plan parcial de desarrollo urbano para la Delegación Felipe Carrillo Puerto, periódico oficial. Querétaro: Gobierno del Estado de Querétaro; 2018. Available from: http://ordenjuridico.gob.mx/Estatal/QUERETARO/ Municipios/Queretaro/3Plan.pdf.

23. Flores J. Efectividad del programa de estimulación temprana en el desarrollo psicomotor de niños de 0 a 3 años. Rev CYT. 2013;9:101-17.

24. Child growth standards. Curvas de peso para la estatura. Geneva: World Health Organization; 2020.

25. Detección del trastorno específico del desarrollo psicomotor en niños de 0 a 3 años. Mexico City: Centro Nacional de Excelencia Tecnológica en Salud; 2014

26. Schönhaut L, Schönstedt M, Álvarez J, Salinas P, Armijo I. Desarrollo psicomotor en niños de nivel socioeconómico medio-alto. Rev Chil Pediatr. 2010;81:123-8.

27. Román Sacón J, Calle Contreras P. Estado de desarrollo psicomotor en niños sanos que asisten a un centro infantil en Santo Domingo, Ecuador. Enfermería (Montevideo). 2017;6:49-65.

28. Centro Nacional para la Salud de la Infancia y Adolescencia. Estimulación temprana. Lineamientos técnicos. Mexico City: Secretaría de Salud; 2002. Available from: http://www.salud.gob.mx/unidades/cdi/documentos/ Estimulacion_Temprana.pdf. 